\title{
Comments on "Sleep terror disorder: a case report"
}

\section{Comentários sobre "Terror noturno: relato de caso"}

\section{Dear Editor,}

The presence of parasomnias in the pediatric clinical practice is quite common and requires attention and knowledge of the general pediatrician and the clinical psychiatrist. An important point of the treatment is the education and reassurance of the parents, whose objective is to explain that such conditions are generally benign, with no significant complications and of limited course ${ }^{1}$.

With regard to the importance of these conditions, we have read Guzman and Wang's ${ }^{2}$ letter with utmost pleasure, since it was published in a psychiatry journal allowing psychiatrists to be more alert about sleep disorders.

However, we noted some points that remained unclear and we think that it is important to clarify them, to better inform and teach clinical psychiatrists who will be faced with these disorders in their offices.

First of all, we reinforce that the presence of a psychopathology is rare in children with sleep terrors; it is often a benign and timelimited condition.

More recent data than that referenced in the letter have clarified the question about the real prevalence of sleep terror in children. The estimation of the prevalence is difficult, because it may be hard for parents to establish a difference between sleep terrors and somnambulism in questionnaires, once questions ask about retrospective symptoms and refer to both parasomnias in the same question. Taking that into account, numbers vary from $1.3 \%$ to $27 \%^{3}$ or even 0 to $40 \%{ }^{4}$.

It is not clear if the statement "As a result, these disorders are more common in children who have more delta sleep" means that children have more delta sleep, which is true, or if those children with more delta sleep would develop more common episodes of parasomnia. Indeed, recently published data show that children with parasomnia may have low delta power in the first sleep cycle and slow decline of delta power in successive sleep cycles, suggesting a chronic inability to sustain slow-wave sleep ${ }^{5}$, but no data affirm that the increase of delta sleep per se would be a risk factor.

The treatment orientation indeed does not include age as a factor when initiating medication; this decision is taken merely based on the severity of the disorder. Of note, sometimes it is difficult for parents to accept giving their little children controlled medication (as benzodiazepines) although they have been prescribed by their doctor, however this does not lead to serious consequences ${ }^{1}$.

In order to prevent psychiatrists from giving selective serotonin reuptake inhibitors to their cases of sleep terror, we must emphasize that the first choice of pharmacological treatment is a benzodiazepine or a tricyclic antidepressant. The time of treatment must be at least 3 months and if a good response is achieved, treatment should not last for more than 6 months. We have had excellent outcomes in our outpatient clinic ambulatory with the use of clonazepam, 1 to 5 drops $(0.125 \mathrm{mg}$ to $0.625 \mathrm{mg}$ ) at bedtime.

João Guilherme Fiorani Borgio Department of Psychiatry, Universidade Federal de São Paulo (Unifesp), São Paulo (SP), Brazil

Márcia Pradella-Hallinan Department of Psychobiology, Universidade Federal de São Paulo (Unifesp), São Paulo (SP), Brazil 


\section{Disclosures}

\begin{tabular}{|c|c|c|c|c|c|c|c|}
\hline $\begin{array}{l}\text { Writting group } \\
\text { member }\end{array}$ & Employment & Research grant $^{1}$ & $\begin{array}{c}\text { Other research grant or } \\
\text { medical continuous } \\
\text { education }\end{array}$ & $\begin{array}{l}\text { Speaker's } \\
\text { honoraria }\end{array}$ & $\begin{array}{l}\text { Ownership } \\
\text { interest }\end{array}$ & $\begin{array}{l}\text { Consultant/ } \\
\text { Advisory } \\
\text { board }\end{array}$ & Other $^{3}$ \\
\hline $\begin{array}{l}\text { João Guilherme } \\
\text { Fiorani Borgio }\end{array}$ & UNIFESP & --- & --- & --- & --- & --- & --- \\
\hline $\begin{array}{l}\text { Márcia Pradella- } \\
\text { Hallinan }\end{array}$ & UNIFESP & --- & -- & --- & -- & --- & --- \\
\hline $\begin{array}{l}{ }^{*} \text { Modest } \\
{ }^{* *} \text { Significant } \\
\text { N** Significant. Amo Amo } \\
\text { Note: UNIFESP = U } \\
\text { For more informatior }\end{array}$ & $\begin{array}{l}\text { iven to the au } \\
\text { idade Federa } \\
\text { Instructions }\end{array}$ & $\begin{array}{l}\text { titution or to a col } \\
\text { Paulo. } \\
\text { rs. }\end{array}$ & for research in which the a & has partic & not directly & author. & \\
\hline
\end{tabular}

\section{References}

1. Mason TB, 2nd, Pack Al. Sleep terrors in childhood. J Pediatr. 2005;147(3):388-92.

2. Guzman CS, Wang YP. Sleep terror disorder: a case report. Rev Bras Psiquiatr. 2008;30(2):169.

3. Tomas Vila M, Miralles Torres A, Beseler Soto B, Revert Gomar M, Sala Langa MJ, Uribelarrea Sierra Al. Sleep patterns and sleep disturbances among schoolchildren in the town of Gandia. An Pediatr (Barc). 2008;68(3):250-6.

4. Petit D, Touchette E, Tremblay RE, Boivin M, Montplaisir J. Dyssomnias and parasomnias in early childhood. Pediatrics. 2007;119(5):e1016-25.

5. Szelenberger W, Niemcewicz S, Dabrowska AJ. Sleepwalking and night terrors: psychopathological and psychophysiological correlates. Int Rev Psychiatry. 2005;17(4):263-70. 